\title{
Investigation of the Effect of Positive Psychological Capital on School Effectiveness
}

\author{
Davut Atış, Ministry of National Education of Turkey, 0000-0001-8503-4426 \\ Çetin Terzi, Anadolu University, 0000-0002-1413-8233
}

\begin{abstract}
This study aims to examine the relationship between school effectiveness and positive psychological capital in the context of public and private schools. The population of the research, in which the relational scanning method was used, consisted of 1296 teachers working in public secondary schools and private secondary schools in Tepebaşı in the 2018-2019 academic year; The sample is composed of 734 teachers reached by stratified ratio sampling method. "Psychological Capital Scale" and "Effective School Scale" were used to collect data. Descriptive and inferential statistics such as mean, standard deviation, correlation coefficients, and data analysis were used to analyse the data. According to teachers' opinions working in both public and private schools, when the findings obtained from the research were examined, there was a significant positive relationship between school effectiveness and the sub-dimensions of positive psychological capital. It was concluded that the teachers' effective school and positive psychological capital levels working in private schools were higher than the teachers working in public schools. A limited number of studies have been found in the literature examining the relationship between positive psychological capital and school effectiveness in the context of public and private schools. In this context, it is recommended to investigate the subject on different samples and at different levels.
\end{abstract}

Keywords: Effective school, positive psychological capital, private schools, state schools

\author{
(10) \\ Inonu University \\ Journal of the Faculty of \\ Education \\ Vol 22, No 2, 2021 \\ ss. $1750-1778$ \\ DOI: \\ 10.17679/inuefd. 880678
}

Article Type:

Research Article
Received : 19.02.2021

Accepted : 17.06.2021 


\title{
Pozitif Psikolojik Sermayenin Okul Etkililiğine Etkisinin incelenmesi
}

\author{
Davut Atış, Milli Eğitim Bakanlığı, 0000-0001-8503-4426 \\ Çetin Terzi, Anadolu University, 0000-0002-1413-8233
}

Öz

Bu çalışmada okul etkililiği ve pozitif psikolojik sermaye ilişkilerinin devlet okulları ve özel okullar bağlamında incelenmesi amaçlanmıştır. iliş̧kisel tarama yöntemi kullanılan araştırmanın evrenini, 2018-2019 eğitim öğretim yılında Tepebaşı ilçesine bağlı devlet ortaokullarında ve özel ortaokullarda görev yapan 1296 ögrretmen; örneklemini ise tabakalı oranlı örnekleme yöntemiyle ulaşılan 734 öğretmen oluşturmaktadır. Verilerin toplanması için "Psikolojik Sermaye Ölçeği" ve "Etkili Okul Ölçeği" kullanılmıştır. Verilerin analizinde ortalama, standart sapma, korelasyon katsayıları ve regresyon analizi gibi tanımlayıcı ve çıkarımsal istatistiklerden faydalanılmıştır. Araştırmadan elde edilen bulgular incelendiğinde, hem devlet okullarında hem de özel okullarda görev yapan öğretmenlerin görüşlerine göre okul etkililiği ve pozitif psikolojik sermayenin alt boyutları arasında pozitif yönde anlamlı ilişki olduğu görülmüştür. Özel okullarda görev yapan öğretmenlerin etkili okul ve pozitif psikolojik sermaye düzeylerinin devlet okullarında görev yapan öğretmenlere göre daha yüksek düzeyde olduğu sonucuna ulaşılmıştır. Alanyazında pozitif psikolojik sermaye ve okul etkililiği ilişkisinin devlet okulları ve özel okullar bağlamında incelendiği sınırlı sayıda araştırmaya rastlanmıştır. Bu bağlamda konunun farklı örneklemler üzerinde, farklı kademelerde araştırılması önerilmektedir.

Anahtar Kelimeler: Devlet okulları, etkili okul, özel okullar, pozitif psikolojik sermaye

İnönü Üniversitesi

Eğitim Fakültesi Dergisi

Cilt 22, Sayı 2, 2021

ss. $1750-1778$

DOI:

$10.17679 /$ inuefd. 880678

Makale türü:

Araştırma makalesi

Gönderim Tarihi :

19.02.2021

Kabul Tarihi :

17.06.2021

Önerilen Atıf

Atış, D. \& Terzi, Ç. (2021) Pozitif psikolojik sermayenin okul etkililiğine etkisinin incelenmesi, Inönü Üniversitesi Eğitim Fakültesi Dergisi, 22(2), 1750-1778. DOI: 10.17679/inuefd.880678

Bu makale Anadolu Üniversitesi, Eğitim Bilimleri Enstitüsü tarafından Eylül, 2020 tarihinde kabul edilen "Okul etkililiği ve pozitif psikolojik sermaye ilişkilerine ilişkin öğretmen görüşleri" başlıklı doktora tezinden üretilmiştir. 


\section{Investigation of the Effect of Positive Psychological Capital on}

\section{School Effectiveness}

Studies on the improvement and development of schools have been discussed in depth since the last quarter of the 21st century (Balcl, 2014; Edmonds, 1979; Murphy, 1992; Şişman, 2002). Making schools effective is becoming more and more important in many aspects such as physical facilities, human resources, student, curriculum, parent and environmental relations. It is possible to say that schools that can achieve their goals at the highest level are effective. As can be seen in many education systems, in the Turkish education system; there are problems such as dropping out of school, increasing absenteeism, violence against teachers and administrators, central examination system, students who have difficulty improving themselves in socio-cultural and sports aspects. The solution to the existing problems in the Turkish education system can be achieved by making schools effective in multiple dimensions and increasing their qualifications. Organizational development can be defined as the series of activities carried out to enable the organization to solve its problems and adapt to environmental changes. Organization development; It is an understanding that foresees the holistic change of people, technology, structure and organizational processes. (Özdemir, 2000, p.34). The concept of an effective school is at the centre of school improvement, school reform and school improvement work. Murphy (1992) argues that effective school action can demonstrate the educational goals of all students at a certain level and the performance results expected from them. Murphy's work lays the foundation for school development, which focuses on school responsibility, learning-centred teaching, the overall environment and results.

Effective school studies show that there are some key components of an effective school. According to Balcl (2014), who conducted pioneering studies on effective schools in Turkey, the sub-dimensions of effective schools are; school administrators, teachers, students, 
parents and school environment. Şişman (1996) classified the dimensions of school

effectiveness as; school administrators, teachers, students, school environment and parents, organizational culture and climate, school program and educational process. Studies and practices on school effectiveness show that school principals, who contribute to the learning of students and the effectiveness of human resources, have an important role in school development processes. Similarly, teachers have a very important role in school effectiveness (Hallinger \& Heck, 1998, p. 158). Effective teacher behaviours can be defined as activating students, doing their job passionately, having a good sense of humour, making students active, cooperating with colleagues, dealing with students' problems, and being democratic, polite and patient (Boulder, 2020; Can, 2004). In the student dimension, effective schools are defined as schools that provide the physical conditions necessary to maximize their students' success, use all school resources efficiently, and provide an environment for students to develop cognitively and socially (Helvacı and Aydoğan, 2011). Schools are in constant interaction with their environment. According to Smith (2004), schools that can establish close relationships with external stakeholders are more effective. Becker (1992) states that cooperation with parents increases school effectiveness. Another component of an effective school is the school culture, which includes norms, values, beliefs, expectations, traditions and interactions shared by the stakeholders that make up the school community (Schein, 2011). In the literature, the dimensions of the effective school within the scope of the research; studies are showing that student success affects concepts such as transformational leadership, organizational commitment, self-efficacy (Güngör, 2018; Jacobson \& Lombard, 1992; Kelekçi \& Yılmaz, 2015). Among these organizational variables, it is predicted that positive psychological capital, which has gained importance in recent years and has been the subject of research, may also be associated with the effective school. In this context, positive psychological capital and its components and the relationship between positive psychological capital and school effectiveness are discussed. 
The reflections of the positive psychology approach on education, which emerged due to the change in the psychological science perspective, which is insufficient to meet the constantly changing expectations and needs of individuals, have been inevitable. The concept of positive psychology was first used in the last part of Maslow's work titled "Motivation and Personality" under the title "Towards Positive Psychology". In this chapter, Maslow opposes the frequent focus of psychology on unfavourable conditions, saying: "Psychology focuses on negative aspects rather than positive ones. Psychology seems to have voluntarily limited itself to half its real task, the darker, the worse." (Maslow, 1954, p. 292). Similarly, since the early 1990s, Seligman and his colleagues opened the way for the emergence of positive psychology, as the field of psychology began to question the negative perspective that focused on people's diseases and defects. In the context of Seligman's thinking, the three main goals of psychology are: "To cure mental illness, to increase people's life satisfaction, and to make people aware of what their abilities are and what they can do with their strength." (Seligman, 2002, p.4). The reflections of the positive psychology approach on education, which emerged due to the change in the psychological science perspective, which is insufficient to meet the constantly changing expectations and needs of individuals, have been inevitable. The concept of positive psychology was first used in the last part of Maslow's work titled "Motivation and Personality" under the title "Towards Positive Psychology". In this chapter, Maslow opposes the frequent focus of psychology on unfavourable conditions, saying: "Psychology focuses on negative aspects rather than positive ones. Psychology seems to have voluntarily limited itself to half its real task, the darker, the worse." (Maslow, 1954, p. 292). Similarly, since the early 1990s, Seligman and his colleagues opened the way for the emergence of positive psychology, as the field of psychology began to question the negative perspective that focused on people's diseases and defects. In the context of Seligman's thinking, the three main goals of psychology are: "To cure mental illness, to increase people's life satisfaction, and to make people aware of what their abilities are and what they can do with their strength." (Seligman, 2002, p.4). The 
"Positive Organizational Behaviour" movement, which is the reflection of positive psychology in organizational life, is defined by Luthans $(2002$, p. 59$)$ as: "to examine the strengths and psychological capacities of human resources that can be measured and developed effectively, to increase the performance of employees and to adapt the scientific knowledge obtained showing a positive way".

One of the major concepts in positive organizational behaviour since the last quarter of the twentieth century is positive psychological capital. With the increasing emphasis on competitive advantage in the workforce, corporate success, and sustainable performance of organizations, positive psychological capital has also gained importance. Luthans et al. (2004) examined economic, social and human capital approaches based on positive psychology and positive organizational behaviour and elaborated these concepts and proposed the concept of psychological capital focusing on the positive aspects of individuals. Thus, it was revealed that positive psychological capital could be organized, produced and directed, and hope, optimism, self-efficacy and resilience were determined as the psychological capital resources of employees. The positive state of psychological capital development in the individual; (1) the confidence to make the energy necessary to succeed in daring tasks (self-efficacy), (2) a positive attribution (optimism) to succeed now and tomorrow, (3) rebuild paths to goals to move forward and be successful when necessary, orientation (hope) and (4) persistence (resilience) to achieve success when surrounded by problems and adversity (Donaldson \& Ko, 2010, p. 16; Kaya et al., 2014, p. 49).

It is seen that positive psychological capital is related to some variables in educational organizations. According to the findings obtained from Demir's (2018) study; There is a negative relationship between teachers' psychological capital levels and their stress levels. It is seen that positive psychological capital has a negative effect on teachers' anxiety levels with the full mediation effect of stress. Positive psychological capital negatively affects teachers' 
burnout levels through partial mediation effects of stress and anxiety. While psychological capital positively affects teachers' job satisfaction through partial mediation effects of stress, anxiety, and burnout, stress, anxiety, burnout, and job satisfaction positively affect teachers' work engagement levels through partial mediation effects.

Some studies in the literature examine the relationship between effective school subdimensions and positive psychological capital sub-dimensions. Taner (2008) investigated the relationship between the hopelessness levels of teachers in public primary schools and school culture in his thesis, and he examined the relationship between the hope dimension of positive psychological capital and the school culture dimension of school effectiveness. The results of the study revealed that there is a positive and significant relationship between strong school culture and teachers' hope levels. Wang et al. (2014), in their study on the dimension of effective school teachers, examined teachers' effective teacher characteristics and positive psychological capital according to various variables and tried to determine the relationship between them. The study revealed a positive and statistically significant relationship between primary school teachers' positive psychological capital levels and their teaching effectiveness. As the psychological capital levels of teachers increase, their teaching activity performances also increase. The relationships between effective school environment and parent dimension, parenting style, and positive psychological capital levels of students from different cultural regions were examined. As part of the curriculum, students can be given interactive and activity-based small projects to develop their resilience, self-efficacy, and optimism (Karmakar, 2016). Uğurlu and Demir (2016) revealed that public and private school teachers' "positive psychological capital" and sub-dimension levels are generally high. Yalçın et al. (2018), in their study examining the relationship between the leadership styles of school administrators and the positive psychological capital of teachers, found that teachers' positive psychological capital was at a high level. According to the findings of the study, transformational leadership style significantly predicts positive psychological capital of 
teachers. According to the results of the research conducted by Çobanoğlu and Bozbayındır (2019) regarding the manager dimension, which is an important dimension of an effective school, it was seen that there is a significant relationship between the leadership styles of effective school managers and their teachers. According to the findings obtained from Çiftçi's (2019) study; there is a statistically significant relationship between the positive psychological capital scale and the sub-dimensions of self-efficacy, optimism, confidence, extraversion, resilience and hope.

According to the studies, it is seen that the dimensions of the effective school are mostly related to the positive psychological capital levels of those working in human resources and educational institutions. It is thought that the positive psychological capital phenomenon contributes significantly to the increase of effective school qualifications. It is expected that this study will contribute to the determination of the relationship between the concepts of school effectiveness and positive psychological capital in public and private schools. It is awaited that this study will determine the degree of relationship between the concepts of positive psychological capital and effective school, guide administrators and teachers to gain positive attitudes and behaviours, and contribute to the schools they work in in terms of being an effective school.

This study examines school effectiveness and positive psychological capital relationships in public and private secondary schools according to teachers' views. The research questions are:

1) What are the teachers' views about effective school?

2) What are the teachers' views on positive psychological capital?

3) What is the relationship between teachers' opinions about effective school and positive psychological capital? 
4) How do the dimensions of positive psychological capital predict the dimensions of the effective school, and how does this predictor change in the context of public and private schools?

\section{Method}

\section{Research Model}

This research was designed in the relational screening model, which is one of the general screening models. The screening model is a research method that tries to explain a past or current situation in its current form. The study is a relational screening model, one of the general screening models investigating the variation between two or more variables, and provides clues about cause-effect relationships. (Büyüköztürk et al., 2020, p. 192; Karasar, 2011; p. 81). This article was produced from the doctoral thesis titled "Teachers' views on the relationship between school effectiveness and positive psychological capital". Ethics committee approval for the research was obtained from Anadolu University Social and Human Sciences Scientific Research and Publication Ethics Committee on 28/03/2019 with protocol number 14833.

\section{The Research Universe and the Sample}

The research universe consists of 1296 teachers, 1075 teachers working in 28 public secondary schools and 221 teachers working in 11 private secondary schools in Eskişehir Tepebaşı in the 2018-2019 academic year. The sample of the study was selected by the stratified proportional sampling method. Stratified sampling can be used when there are substrata or subunits with defined boundaries in a universe (Yıldırım \& Şimşek, 2016, p.116). In proportional stratified sampling, participants from each stratum are included in the sampling as much as their percentage in the universe (De Vaus, 1990, p.66). The ratio of the number of teachers to the population in public and private schools was calculated, and it was seen that 111 teachers could represent the population of the study. The study sample consisted of 734 teachers, $589(80.24 \%)$ from public secondary schools and 145 (19.76\%) from private 
secondary schools, after removing the extreme values from 746 scales. $70 \%$ of the participants are female, and $30 \%$ are male. It was seen that the general average age of teachers participating in the study from public and private schools was 30-39 (53\%). Considering the educational status of the participants, $12 \%$ of those receiving postgraduate education are in public schools, and $18 \%$ are in private schools. In the study, it was seen that the majority of the participants were Mathematics (15.4\%), Turkish (14.3\%), Foreign Language (14.1\%), Science (12.5\%) and Social Studies (8.7\%) teachers.

\section{Data Collection Tools}

In this study, the "Positive Psychological Capital Scale" developed by Tösten and Özgan (2014) was used to determine teachers' psychological capital levels. The scale is a five-point Likert-type scale consisting of 26 items with six dimensions (self-efficacy, optimism, confidence, extraversion, resilience, and hope). The Cronbach Alpha coefficient of the scale was .946 , the total variance explained was $61.6 \%$, the KMO test value was .91, and the Bartlett test value was $.00(p<.01)$ (Tösten \& Özgan, 2014). The researcher performed a confirmatory factor analysis of the scale. The ratio of the scale's Chi-Square Test of Fit (948) to degrees of freedom (282) was 3.3; Comparative Fit Index (CFI) value is .94; Tucker Lewis Index TLI value. 93; Unnormed Fit Index (NNFI) value is .93; Bollen Incremental Fit Index (IFI) value is .94; .05 of the Root Mean Square of Estimation Errors (RMSEA); It was determined that the Standardized Root Mean Square Error (SRMR) value was .04 and the Goodness of Fit Index (GFI) value was .91. In order to determine whether the teachers' positive psychological capital scale has a healthy structure, the factor load values of the items were checked. The load values of the items in the factors are expected to be high. Generally, .50 and higher loads are "high"; A load between .30-50 is seen as "medium" and below .30 as low (Büyüköztürk et al., 2020). Factor loading values of teachers' positive psychological capital scale items It was determined that the factor loads of the items in the five dimensions of the scale were .50 and above; that is, it 
provided convergent validity (Peterson, 2000). As a result of the findings, it was seen that the six-factor structure of the scale had sufficient fit values.

The Effective School Scale developed by Uğurlu and Abdurrezzak (2014) was used in the research. The scale is a five-point Likert type scale consisting of 39 items with five dimensions (administrator, teacher, school environment and educational process, students and school environment and parents). The Cronbach Alpha coefficient of the scale was .950, the total variance explained was $66.27 \%$, the KMO test value was .87 , and the Bartlett test value was $2669.315(p<.05)$. As a result of the analysis, it was seen that the scale gave acceptable fit values (Uğurlu \& Abdurrezzak, 2014). The researcher performed a confirmatory factor analysis of the scale. Chi-square Test of Fit (1443) ratio of scale to degrees of freedom (420) 3.4; Comparative Fit Index (CFI) value is .95; Tucker Lewis Index TLI value of .95; Non-Normal Fit Index (NNFI) value is .95; Bollen Incremental Fit Index (IFI) value is .95; .05 of the Root Mean Square of Estimation Errors (RMSEA); The standardized Root Mean Square Error (SRMR) value is .04, and the Goodness of Fit Index (GFI) value is .88. It was determined that the factor loads of the items in the five dimensions, namely school administrators, teachers, school environment and educational process, students and parents, were .50 and above, thus providing convergent validity (Peterson, 2000). As a result of the findings, it was determined that the five-factor structure of the scale had good fit values.

\section{Data Analysis}

Research data were analyzed with correlation coefficients, multiple variance analysis and regression analysis. Mahalanobis distance values were calculated, and 12 people were removed from the data set, which was 746 in total, and the study was carried out on 734 people. Kurtosis and skewness values between -2 and +2 are required to satisfy the assumption of normality. (George \& Mallery, 2016, Tabachnick \& Fidell, 2013). All the study variables related to effective school and positive psychological capital show the normal distribution in the public school (584 participants) and private school (145 participants) groups. 
The skewness values for teachers working in public schools are between -0.29 and -1.43 , while for private school teachers, this value is between 0.02 and -0.99 . Kurtosis values are between 0.24 and 1.90 for teachers working in public schools, while this value is between 0.01 and 1.20 for private school teachers. As a result, it was seen that all normality conditions were met. All assumptions were tested for the regression analysis performed. Analyzes in the study were made with the IBM SPSS 26 program. The construct validity of the "Effective School Scale" and "Positive Psychological Scale" scales was tested using the R package program (R Core Team, 2013) 'Lavaan' package (Rosseel, 2012).

In the study, descriptive statistical calculations of percentage, frequency, arithmetic mean, and standard deviation were made to determine teachers' views on effective school and positive psychological capital. A correlation analysis was conducted to examine the relationship between the effective school and teachers' views on positive psychological capital. Multiple Linear Regression Analysis was conducted to determine whether the positive psychological capital dimensions significantly predicted the dimensions of the effective school and whether this predictor changed in the context of public and private schools.

\section{Findings}

\section{Teachers' Views on School Effectiveness}

In this section, the findings related to the sub-problem "What are the teachers' views on effective school?" are included. Table 1 presents the findings of teachers' views on effective school and its sub-dimensions.

\section{Chart 1}

Findings of teachers' opinions on effective school and its sub-dimensions

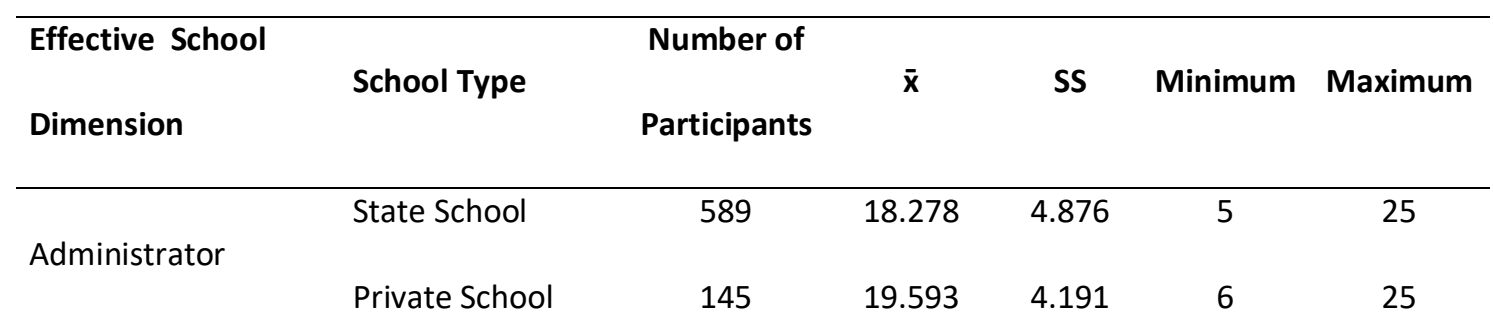




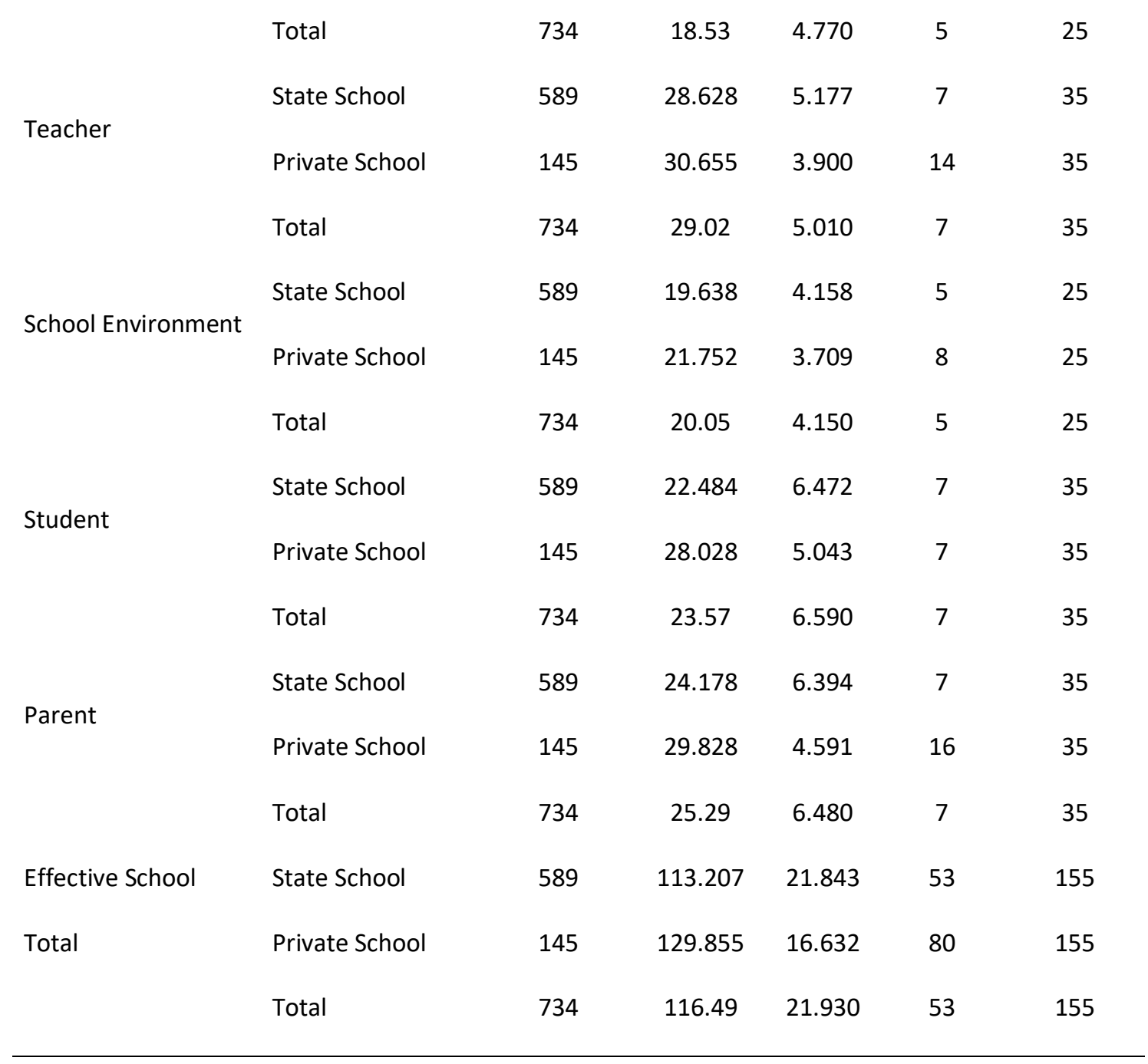

When Chart 1. is examined, according to the findings of teachers' views on the subdimensions of effective school and effective school, it was seen that all participant teachers' perceptions of effective school ( $\bar{x}=16.49)$ were at a "high" level. Considering the type of institution, it is understood that private school teachers' perceptions of effective school $(\bar{x}=129.85)$ are higher than public school teachers' effective school perceptions $(\bar{x}=113.20)$. It is also seen that the effective school perceptions of private school teachers are higher than public school teachers in all sub-dimensions. Teachers' perceptions of effective school teacher $(\bar{x}=29.02)$ and school environment and educational process $(\bar{x}=20.05)$ sub-dimensions; administrator $(\bar{x}=18.53)$, student $(\bar{x}=23.57)$ and parent $(\bar{x}=25.29)$ sub-dimensions. When the findings are evaluated, it is seen that teachers have the highest teacher factor in terms of meeting the effective school characteristics of the institutions they work, followed by the 
school environment and education process, administrator, parent and student dimensions, respectively.

\section{Teachers' Views on Positive Psychological Capital}

In this section, findings regarding the sub-problem "What are the teachers' views on positive psychological capital?" are given. Table 2 includes findings regarding teachers' opinions on positive psychological capital.

\section{Chart 2}

Findings of teachers' views on positive psychological capital and its sub-dimensions

\begin{tabular}{|c|c|c|c|c|c|c|}
\hline Positive Psychological & & Number of & & & & \\
\hline & School Type & & $\overline{\mathbf{x}}$ & SS & Minimum & Maximum \\
\hline Capital Dimension & & Participants & & & & \\
\hline & State School & 589 & 18.171 & 1.748 & 10 & 20 \\
\hline & Private & & & & & \\
\hline Self-efficacy & & 145 & 18.662 & 1.753 & 12 & 20 \\
\hline & School & & & & & \\
\hline & Total & 734 & 18.26 & 1.750 & 10 & 20 \\
\hline & State School & 589 & 21.424 & 3.059 & 10 & 25 \\
\hline Optimism & Private & & & & & \\
\hline & & 145 & 21.786 & 3.398 & 13 & 25 \\
\hline & School & & & & & \\
\hline & Total & 734 & 18.74 & 1.660 & 13 & 20 \\
\hline & State School & 589 & 18.676 & 1.646 & 13 & 20 \\
\hline Confidence & Private & & & & & \\
\hline & & 145 & 19.007 & 1.694 & 14 & 20 \\
\hline & School & & & & & \\
\hline & Total & 734 & 21.49 & 3.130 & 10 & 25 \\
\hline & State School & 589 & 21.98 & 2.682 & 12 & 25 \\
\hline Extraversion & Private & & & & & \\
\hline & & 145 & 23.13 & 2.123 & 18 & 25 \\
\hline & School & & & & & \\
\hline & Total & 734 & 22.21 & 2.62 & 12 & 25 \\
\hline Resilience & State School & 589 & 21.76 & 2.790 & 12 & 25 \\
\hline
\end{tabular}




\begin{tabular}{|c|c|c|c|c|c|c|}
\hline & \multicolumn{6}{|l|}{ Private } \\
\hline & & 145 & 22.85 & 2.458 & 15 & 25 \\
\hline & \multicolumn{6}{|l|}{ School } \\
\hline & Total & 734 & 21.98 & 2.760 & 12 & 25 \\
\hline & State School & 589 & 13.33 & 1.681 & 6 & 15 \\
\hline \multirow[t]{5}{*}{ Hope } & Private & & & & & \\
\hline & & 145 & 13.55 & 1.394 & 10 & 15 \\
\hline & School & & & & & \\
\hline & Total & 734 & 13.37 & 1.630 & 6 & 15 \\
\hline & State School & 589 & 115.35 & 10.608 & 79 & 130 \\
\hline \multicolumn{7}{|c|}{ Psychological Capital } \\
\hline & Private & & & & & \\
\hline \multirow[t]{3}{*}{ Total } & & 145 & 119.00 & 9.991 & 94 & 130 \\
\hline & School & & & & & \\
\hline & Total & 734 & 116.07 & 10.58 & 79 & 130 \\
\hline
\end{tabular}

Findings regarding the teachers' views on positive psychological capital and its subdimensions show that all participating teachers have a "high" $(\bar{x}=116.07)$ level of positive psychological capital perception. It is understood that private school teachers' positive psychological capital perceptions $(\bar{x}=119)$ are higher than public school teachers' positive psychological capital perceptions ( $\bar{x}=115.35)$. In addition, it is seen that the positive psychological capital perceptions of private school teachers are higher than public school teachers in all sub-dimensions. Teachers' perceptions of positive psychological capital, optimism ( $\bar{x}=18.26)$ and self-efficacy $(\bar{x}=18.26)$ sub-dimensions; hope $(\bar{x}=13.37)$, extraversion $(\bar{x}=22.21)$, resilience $(\bar{x}=21.98)$ and confidence $(\bar{x}=21.49)$ sub-dimensions were found to be higher than their perceptions. When the findings were examined, it was seen that the dimensions of self-efficacy, hope, extraversion, resilience and confidence followed the optimism dimension at the highest level in terms of meeting the positive psychological capital characteristics of the teachers, respectively.

\section{The Relationship Between Effective School and Positive Psychological Capital}

In this section, Findings regarding the sub-problem "Is there a relationship between teachers' views of effective school and their views of positive psychological capital?" are given. 


\section{Chart 3.}

Correlation coefficients showing the relationship between positive psychological capital dimensions and effective school dimensions of teachers working in public schools $(N=589)$

\begin{tabular}{|c|c|c|c|c|c|c|c|c|c|c|c|}
\hline Variables & 1 & 2 & 3 & 4 & 5 & 6 & 7 & 8 & 9 & 10 & 11 \\
\hline 1.Administrator & - & & & & & & & & & & \\
\hline 2.Teacher & $.56 * *$ & - & & & & & & & & & \\
\hline 3.School Env. & $.67 * * *$ & $.71 * * *$ & - & & & & & & & & \\
\hline 4.Student & $.48 * * *$ & $.48 * * *$ & $.55^{* * *}$ & - & & & & & & & \\
\hline 5.Parents & $.47^{* * *}$ & $.45 * * *$ & $.53 * * *$ & $.73 * * *$ & - & & & & & & \\
\hline 6.Self-efficacy & $.14^{* * *}$ & $.25 * * *$ & $.24 * * *$ & $.23^{* * *}$ & $.21 * * *$ & - & & & & & \\
\hline 7.Optimism & $.17^{* * *}$ & $.26 * * *$ & $.25 * * *$ & $.26 * * *$ & $.24 * * *$ & $.46 * * *$ & - & & & & \\
\hline 8.Confidence & $.16^{* * *}$ & $.26 * * *$ & $.19 * * *$ & $.20 * * *$ & $.21 * * *$ & $.59 * * *$ & $.44 * * *$ & - & & & \\
\hline 9. Extraversion & $.24 * * *$ & $.27 * * *$ & $.22 * * *$ & $.20 * * *$ & $.20 * * *$ & $.52 * * *$ & $.47 * * *$ & $.59 * * *$ & - & & \\
\hline 10.Resilience & $.25^{* * *}$ & $.30 * * *$ & $.29 * * *$ & $.30 * * *$ & $.29 * * *$ & $.48 * * *$ & $.50 * * *$ & $.53 * * *$ & $.66 * * *$ & - & \\
\hline 11.Hope & $.24 * * *$ & $.28 * * *$ & $.27^{* * *}$ & $.25^{* * *}$ & $.25 * * *$ & $.50 * * *$ & $.44 * * *$ & $.52 * * *$ & $.52 * * *$ & $.65 * * *$ & - \\
\hline
\end{tabular}

When Chart 3 is examined, the correlation coefficients between teachers' positive psychological capital dimensions working in public schools and the effective school dimensions vary between .14 and .73. In addition, it was determined that there was no multicollinearity problem since there was no relationship above .80 between the independent variables (Pallant, 2007, p. 149). There is a positive relationship between administrators and selfefficacy, optimism, confidence, extraversion, resilience and hope, which are the dimensions of an effective school. There is a positive relationship between teachers and self-efficacy, optimism, confidence, extraversion, resilience and hope, which are the dimensions of an effective school. There is a positive relationship between school environment and self-efficacy, optimism, confidence, extraversion, resilience and hope, which are among the effective school dimensions. There is a positive relationship between student and self-efficacy, optimism, 
confidence, extraversion, resilience and hope, among the dimensions of an effective school.

There is a positive relationship between parents and self-efficacy, optimism, confidence, extraversion, resilience and hope, which are among the dimensions of an effective school.

\section{Chart 4}

Correlation coefficients showing the relationship between positive psychological capital dimensions and effective school dimensions of teachers working in private schools $(N=145)$

\begin{tabular}{|c|c|c|c|c|c|c|c|c|c|c|c|}
\hline & 1 & 2 & 3 & 4 & 5 & 6 & 7 & 8 & 9 & 10 & 11 \\
\hline 1.Administrator & - & & & & & & & & & & \\
\hline 2.Teacher & $.56 * * *$ & - & & & & & & & & & \\
\hline 3.School Env. & $.56 * * *$ & $.66 * * *$ & - & & & & & & & & \\
\hline 4.Student & $.42 * * *$ & $.45 * * *$ & $.47 * * *$ & - & & & & & & & \\
\hline 5.Parents & $.46 * * *$ & $.38 * * *$ & $.39 * * *$ & $.66 * * *$ & - & & & & & & \\
\hline 6.Self-efficacy & $.33 * * *$ & $.38 * * *$ & $.31 * * *$ & $.36 * * *$ & $.39 * * *$ & - & & & & & \\
\hline 7.Optimism & $.19 *$ & $.24^{* *}$ & .08 & $.35 * * *$ & $.20^{*}$ & $.56 * * *$ & - & & & & \\
\hline 8.Confidence & $.21^{*}$ & $.31 * * *$ & $.18^{*}$ & $.37 * * *$ & $.37 * * *$ & $.61 * * *$ & $.50 * * *$ & - & & & \\
\hline 9.Extraversion & $.30 * * *$ & $.26 * *$ & $.17^{*}$ & $.28 * * *$ & $.28 * * *$ & $.62 * * *$ & $.50 * * *$ & $.55 * * *$ & - & & \\
\hline 10.Resilience & $.26^{* *}$ & $.38 * * *$ & $.20^{*}$ & $.34 * * *$ & $.24 * *$ & $.53 * * *$ & $.45 * * *$ & $.53 * * *$ & $.59 * * *$ & - & \\
\hline 11.Hope & $.19^{*}$ & $.26 * *$ & .10 & .15 & $.17^{*}$ & $.50 * * *$ & $.35 * * *$ & $.46 * * *$ & $.48 * * *$ & $.65 * * *$ & - \\
\hline
\end{tabular}

$* \mathrm{p}<.05, * * \mathrm{p}<.01, * * * \mathrm{p}<.001$

When Chart 4 is examined, the correlation coefficients between the dimensions of positive psychological capital and effective school dimensions of teachers working in private schools vary between .17 and 66 . In addition, it was determined that there was no multicollinearity problem since there was no relationship above .80 between the independent variables (Pallant, 2007, p. 149). There is a positive relationship between administrators and self-efficacy, optimism, confidence, extraversion, resilience and hope, which are the dimensions of an effective school. There is a positive relationship between teachers and selfefficacy, optimism, confidence, extraversion, resilience and hope, which are the dimensions of 
an effective school. While there is a positive relationship between the environment of effective school dimensions and self-efficacy, confidence, extraversion and resilience, there is no relationship between optimism and hope. While there is a positive relationship between students and self-efficacy, optimism, confidence, extraversion and resilience, which are among the dimensions of an effective school, there is no relationship between hope and hope. There is a positive relationship between parents and self-efficacy, optimism, confidence, extraversion, resilience and hope, among the dimensions of an effective school.

\section{Findings on the predictors of administrators from the effective school sub-dimensions}

In this section, the findings related to the sub-problem "Do the positive psychological capital dimensions significantly predict the dimensions of the effective school and does this prediction vary in the context of public and private schools?" are given.

According to the results of the regression analysis of public school teachers' predictors of administrators, the model is significant for public schools $\left(F={ }_{(6,582)}=8.65, p<.001, R^{2}=.08\right)$. When the variables predicting managers were examined, it was seen that extraversion ( $\beta=$ .13) and hope $(\beta=.13)$ predicted positively. On the other hand, it was determined that selfefficacy, optimism, confidence and resilience were not predictors. Extraversion and hope explain $8 \%$ of the public school teachers' dimension of the administrator dimension. When the results of the regression analysis of the predictors of private school teachers' administrators were examined, the model for private schools was found to be significant $\left(F={ }_{(6,138)}=3.48, p\right.$ $\left.<.001, R^{2}=.13\right)$. When the variables predicting the administrators were examined, it was seen that only self-efficacy predicted positively $(\beta=.26)$. School administrators' self-efficacy levels increase in direct proportion to their level of being effective school administrator. On the other hand, it was determined that optimism, confidence, extraversion, resilience and hope were not predictors. Self-efficacy explains $9 \%$ of private school teachers' managerial dimension. As a result, only the self-efficacy of private school teachers predicts the effective school administrator dimension. On the other hand, as public school teachers' extraversion 
characteristics and hope levels increase, their perceptions of effective school administrators increase.

\section{Findings on teachers' predictors of effective school sub-dimensions}

This study aims to determine whether positive psychological capital variables significantly predict the dimension of effective teachers working in public and private schools. These relationships are compared in the context of public and private schools. The regression analysis results of the public school teachers regarding the teachers' predictors prove that the model is significant for the teacher dimension in public schools $\left(F={ }_{(6,582)}=13.41, p<.001, R^{2}=\right.$ .12). When the variables predicting teachers are examined, optimism $(\beta=.10)$ and hope $(\beta=$ .09) positively predicted. It was determined that extraversion and resilience were not predictors, while optimism and hope explained $11 \%$.

According to the results of the regression analysis of private school teachers' predictors of teachers, the model was found to be significant for private schools $\left(F={ }_{(6,138)}=\right.$ $\left.5.47, p<.001, R^{2}=.19\right)$. When the variables that predict teachers from effective school dimensions are examined, it is seen that self-efficacy $(\beta=.27)$ and psychological resilience $(\beta=$ .28) predict positively. As teachers' self-efficacy and resilience levels working in private schools increase, their perceptions of effective school teachers also increase. On the other hand, it was seen that optimism, confidence, extroversion and hope were not predictors. Self-efficacy and resilience explain $16 \%$ of the teacher dimension of private school teachers. As a result, the effective school teacher dimension of private school teachers predicts self-efficacy and psychological resilience. In other respects, as the level of optimism of public school teachers increases, their perceptions of effective school teachers also increase.

Findings on the school environment and predictors of the educational process, among the sub-dimensions of effective school

In the study, multiple linear regression analysis was used to determine whether positive psychological capital variables significantly predicted the effective school environment 
and educational process dimension working in public and private schools. These relationships were compared in the context of public school and private school. Regression analysis results of public school teachers' school environment and predictors of the educational process show that the model is significant for the school environment and educational process dimension in public schools $\left(F={ }_{(6,582)}=12.07, p<.001, R^{2}=.11\right)$. When the variables that predict the school environment and education process are examined, it is seen that self-efficacy predicts positive $(\beta=.10)$, optimism $(\beta=.10)$, and resilience $(\beta=.15)$. As public school teachers' self-efficacy, optimism and resilience levels increase, their perceptions of the effective school-school environment and educational process also increase. However, confidence and extroversion were not found to be predictors. Self-efficacy, optimism and resilience explain $10 \%$ of the school environment and educational process dimension of teachers working in public schools.

According to the results of regression analysis of private school teachers' school environment and predictors of the educational process, the model was found to be significant for private schools $\left(F={ }_{(6,138)}=5.47, p<.001, R^{2}=.13\right)$. The variables that predict the school environment and education process, which are among the effective school dimensions, are examined; only self-efficacy was a positive predictor $(\beta=.40)$. On the other hand, it was determined that optimism, confidence, extraversion, resilience and hope were not predictors. Self-efficacy explains $9 \%$ of private school teachers' school environment and educational process dimension. As a result, only self-efficacy predicts the dimensions of an effective school, school environment, and educational process of private school teachers. As hope levels increase, the perception of an effective school, school environment and educational process increase.

\section{Findings on the predictors of students, one of the sub-dimensions of effective school}

Regression analysis results of public school teachers' predictors of students show that the model is significant for student size in public schools $\left(F={ }_{(6,582)}=12.15, p<.001, R^{2}=.11\right)$. When the variables predicting the student were examined, it was seen that optimism $(\beta=.13)$ 
and psychological resilience $(\beta=.19)$ predicted positively. As teachers' optimism and resilience levels increase in public schools, their perceptions of effective school students also increase. On the other hand, it was determined that self-efficacy, confidence, extraversion and hope were not predictors. Optimism and resilience explain that students $10 \%$ of the size of public school teachers.

When the results of the regression analysis of private school teachers' predictors of students are examined; the model was found to be significant for private schools $\left(F={ }_{(6,138)}=\right.$ $\left.6.44, p<.001, R^{2}=.22\right)$. When the variables predicting students were examined, it was seen that confidence $(\beta=.18)$ and psychological resilience $(\beta=.25)$ predicted positively, while hope predicted negatively $(\beta=-.22)$. As a result, as private school teachers' confidence and resilience levels increase, student perceptions increase. On the other hand, it can be said that as teachers' hope level increases, their perception of effective school students decreases. Confidence, resilience and hope explain $18 \%$ of the number of students working in private schools. As a result, confidence, resilience, and hope predict the size of private school teachers' effective school students. On the other hand, as public schools and teachers' optimism and resilience levels increase, the perception of effective school students also increases.

\section{Findings on parents' predictors of effective school sub-dimensions}

In the study, multiple linear regression analysis was conducted to determine whether positive psychological capital variables significantly predicted the effective school parent dimension of public and private school teachers. These relationships that emerged as a result of the analysis were compared in public schools and private schools. Regression analysis results of public school teachers' predictors of parents show that the model is significant for parent dimension in public schools $\left(F={ }_{(6,582)}=10.91, p<.001, R^{2}=.10\right)$. When the variables predicting parents were examined, it was seen that optimism $(\beta=.10)$ and psychological resilience $(\beta=.18)$ predicted positively. As public school teachers' optimism and resilience 
levels increase, their perceptions of effective school parents also increase. On the other hand, it was understood that self-efficacy, confidence, extraversion and hope were not predictors. Optimism and resilience explain $9 \%$ of public school teachers.

According to the results of the regression analysis of private school teachers' predictors of parents, the model was found to be significant for private schools $\left(F={ }_{(6,138)}=\right.$ 5.39, $\left.p<.001, R^{2}=.19\right)$. When the variables predicting the parents are examined, self-efficacy $(\beta=.32)$ and confidence $(\beta=.23)$ were found to predict positively. As the self-efficacy and confidence levels of private school teachers increase, the perception of effective school parents also increases. On the other hand, it was concluded that optimism, extroversion, resilience and hope were not predictors. Self-efficacy and confidence explain $15 \%$ of the parent dimension of private school teachers. As a result, self-efficacy and confidence predict the effective school parent dimension of private school teachers. On the other hand, as the levels of optimism and resilience of employees in public schools increase, their perceptions of effective school parents also increase.

\section{Discussion and Conclusion}

According to the research findings, when the data obtained in the context of teachers' views on effective school are examined, it is seen that the teacher dimension is at the highest level. It is seen that this dimension is followed by the school environment and educational process, administrator, parent and student dimensions. When the findings obtained from the study are compared to the results obtained from the study of Gökçe and Kahraman (2010), in which they evaluated the opinions of teachers about effective school in the dimensions of leadership, teaching, organizational commitment and professional development, and schoolenvironment relations, they found that there were problems in the dimension of schoolenvironment relations. It is seen that the current study does not overlap in terms of the fact that the parent dimension is at a lower level than the other effective school dimensions. According to the findings obtained from the studies of Helvacı and Aydoğan (2011), it is seen 
that the most important characteristics of the teachers regarding the effective school are, respectively, the school's realization of the education-teaching service in the best way, giving importance to the school-environment relationship and creating a positive school climate and culture. Considering that the dimensions of an effective school teacher, school environment and educational process and administrator characteristics are at the highest level, respectively, according to the findings obtained from the current study, it can be said that the current study and the findings obtained from the studies of Helvacı and Aydoğan (2011) do not partially overlap. In both studies, it can be said that there is a partial similarity since the education process is seen as an important variable by the teachers. On the other hand, in the present study, according to the teachers' opinions, it was found that private school teachers are more effective than public school teachers in terms of administrators, teachers, students, school environment, education and training process and parents. It is possible to say that this result is similar to the finding of the research conducted by Arslan et al. (2010) that private schools are more effective than public schools in terms of inputs, school climate, conditions and learningteaching process.

When we look at the findings of positive psychological capital, while optimism is at the highest level in meeting teachers' positive psychological capital characteristics, this dimension is followed by self-efficacy, extraversion, resilience and confidence, respectively. According to the findings obtained from this study, while the "optimism" dimension, one of the positive psychological capital dimensions of teachers, is at the highest level, in terms of positive psychological capital sub-dimensions of Kelekçi and Yılmaz (2015) and Yalçın (2019), the dimension in which teachers have the highest average is "confidence". It can be said that the studies do not coincide with the findings of the current study.

In the current study, a significant positive relationship was found between the effective school teacher dimension and the positive psychological capital sub-dimensions in the context of school effectiveness and positive psychological capital relations. According to 
the findings of the study conducted by Wang et al. (2014), it is seen that as teachers' psychological capital levels increase, their effective teaching performance also increases. In this respect, the present study's findings support the findings of Wang et al. (2014).

In the study conducted by Uğurlu and Demir (2016), it was revealed that teachers working in both public and private schools generally have a high level of positive psychological capital and components. In this study, the mean and standard deviation values of the factors at the dimension level of the scales were determined. On the other hand, considering teachers' positive psychological capital dimension in public and private schools in the present study, it was seen that private school teachers had a higher level of perception. As an example of this situation, performance evaluation studies and motivation in private schools are higher than in public schools. On the other hand, due to the structure of public schools, teacher selection and development is carried out by the Ministry of National Education in Turkey, and it is thought that they progress in a different course than private schools. Teachers working in private schools are personally selected by the owner of the institution and the administrators of the institution. In this context, it is easier to choose teachers who are suitable for the institution's structure. Thus, commitment to the institution, compliance with the mission and vision also constitute the variables that positively affect the positive psychological capital. Yalçın et al. (2018) examined the relationship between school administrators' leadership styles and teachers' positive psychological capital and concluded that teachers' positive psychological capital was at a high level. The study also revealed that an effective leadership style predicts positive psychological capital positively. The findings of the current study in this context support the research findings conducted by Yalçın et al. (2018).

According to the teachers' opinions, the research findings show a significant and positive relationship between the dimensions of effective school and positive psychological capital. This result coincides with the results of Çobanoğlu and Bozbayındır's (2019) study in which they determined the leadership characteristics and positive psychological capital levels 
of administrators and examined the relationship between these two variables. They found a significant relationship between positive psychological capital and shared leadership characteristics of primary and secondary school teachers. Similarly, according to the findings obtained from Çiftçi's (2019) study, it was determined that there is a statistically significant relationship between school effectiveness and positive psychological capital sub-dimensions. While a "high" level of correlation was found between the variables in the current study, the level of correlation was found to be "low" in Çiftçi's (2019) study.

The research results revealed that teachers' positive psychological capital perceptions regarding private secondary schools were higher than those working in public secondary schools. In line with this finding, it is suggested that qualified education should be given in preservice, in-service training, and in-service training, considering that the positive psychological capital perceptions of teachers working in public secondary schools can be improved. The research revealed that teachers' positive psychological capital perceptions about private secondary schools are higher than those who work in public secondary schools. It is recommended to exchange the best examples of effective private schools for public schools in this context.

When the studies on positive psychological capital and effective school are examined, it is seen that there are a limited number of studies, especially in the Turkish literature. It is recommended to carry out original researches in this field to enrich the literature. This research was carried out in the population of the Tepebaşı district of Eskişehir province. It is recommended that the research be implemented in secondary schools in all provinces within the scope of a project with the support of the Ministry of National Education. This research was conducted in secondary schools. It is recommended that the research be conducted in primary schools, high schools and other educational institutions. The research was designed as quantitative research. It is recommended to conduct qualitative research on the same subject and investigate the mediating roles of positive psychological capital in explaining school 
effectiveness to collect data more comprehensively, detail teachers' views, and reveal the underlying causes.

\section{Interest Statement}

The author (s) have not declared any potential conflicts of interest regarding the research, authorship and / or publication of this article.

\section{Support / Financing Information}

The author (s) did not receive any financial support for research, authorship, and / or publication of this article.

\section{Ethical Committee Decision}

Ethics committee approval, dated 28/03/2019 and protocol numbered 14833, was obtained from Anadolu University Social and Human Sciences Scientific Research and Publication Ethics Committee for this research. 


\section{References}

Arslan, H., Kuru, M., \& Satıcı, A. (2010). Devlet ve özel ilköğretim okullarının etkililiğinin araştırılması. Eğitim ve Bilim, 31 (142). 15-25.

Balcı, A. (2014). Etkili okul okul geliştirme kuram, uygulama ve araştırma. (7. Baskı). Pegem Akademi.

Becker, M. (1992). An effective school primer. Arlington VA: American Association of School Administrators.

Boulder, T. C. (2020). Online strategic discussion forum: models, strategies and applications. M. C. P. O. Okojie and T. C. Boulder (Eds.). In Handbook of research on adult learning in higher education. Pittsburgh: The University of Pittsburgh.

Büyüköztürk, Ş., Çakmak, E. K., Akgün, Ö. E., Karadeniz, Ş., \& Demirci, F. (2008). Bilimsel araştırma yöntemleri. Pegem Akademi.

Can, N . (2004). Öğretmenlerin geliştirilmesi ve etkili öğretmen davranışları. Erciyes Üniversitesi Sosyal Bilimler Enstitüsü Dergisi, 1 (16) , 103-119.

Creswell, J. W. (2003). Research design: Qualitative, quantitative and mixed methods approaches. Sage.

Çiftçi, K. (2019). Ortaokul öğretmenlerinin pozitif psikolojik sermaye düzeyleri ile okul etkililiği düzeyleri arasındaki iliş̧i (Erzurum ili). Yayımlanmamış yüksek lisans tezi, Sakarya Üniversitesi, Sakarya, Türkiye.

Çobanoğlu, N., \& Bozbayındır, F. (2019). A study on shared leadership and positive psychological capitals of teachers at primary and secondary schools. Universal Journal of Educational Research, 7(5), 1265-1274.

Demir, S . (2018). The Relationship between psychological capital and stress, anxiety, burnout, job satisfaction, and job involvement . Eurasian Journal of Educational Research, 18 (75) , 137-154 .

De Vaus, D.A. (1990). Surveys in social research (2nd edition). Harper Collins.

Donaldson, S., \& Ko, I. (2010). Positive organizational psychology, behavior, and scholarship: $A$ review of the emerging literature and evidence base, The Journal of Positive Psychology:Dedicated to furthering research and promoting good practice, 5 (3), 177191.

George, D., \& Mallery, P. (2016). IBM SPSS statistics 23 step by step: a simple guideand reference. Routledge.

Gökçe, F., \& Kahraman P. B. (2010). Etkili okulun bileşenleri: Bursa ili örneği. Uludağ Üniversitesi Eğitim Fakültesi Dergisi. 23 (1) 172-206.

Güngör, A. (2018). Etkili okul özelliklerinin dönüşümsel liderlik ve öğretmen bağılığıyla ilişkisi. Yayımlanmamış doktora tezi. Ege Üniversitesi, İzmir, Türkiye.

Hallinger, P., \& Heck, R. (1998). Exploring the principles' contribution to school effectiveness. School Effectiveness and School Improvement, 9 (2), 157-191.

Helvacı, M. A., \& Aydoğan, í. (2011). Etkili okul ve etkili okul müdürüne ilişkin öğretmen görüşleri. Uşak Üniversitesi Sosyal Bilimler Dergisi, 4 (2), 41-60.

Jacobson, M. G., \& Lombard, R. H. (1992). Effective school climate: roles for peers, practitioners, and principals. Rural Research Report, 3 (4), 1-8.

Karasar, N. (2011). Bilimsel araştırma yöntemi (22. baskı). Nobel Akademi. 
Karmakar, R. (2016). Positive psychological capital and parenting styles among adolescents: Khasi and non-Khasi scenario. Romanian Journal of Applied Psychology, (18) 2, 47-52.

Kaya, A., Balay, R., \& Demirci, Z. (2014). Ortaöğretimde görev yapan öğretmenlerin psikolojik sermaye düzeylerinin incelenmesi (Şanlıurfa ili örneği). Elektronik Sosyal Bilimler Dergisi, 13 (48), 47-68.

Kelekçi, H., \& Yılmaz, K. (2015). Öğretmenlerin pozitif psikolojik sermayeleri ile yeterlik inançları arasındaki ilişki. Mersin Üniversitesi Eğitim Fakültesi Dergisi, 11 (3), 992-1007.

Luthans, F. (2002). Positive organizational behaviour: developing and managing psychological strenghts. Academy of Management Executive, 16(1), 57-72.

Luthans, F., Luthans, K. W., \& Luthans, B.C. (2004). Positive psychological capital: beyond human and social capital. Businness Horizons, 47(1), 45-50.

Maslow, A. (1954). Motivation and personality. Harper \& Row Publishers.

Murphy, J. (1992). School effectiveness and school restructuring: contributions to educational improvement. School Effectiveness and School Improvement, (3), 90-109.

Özdemir, S. (2000). Eğitimde örgütsel yenileşme. Pegem Akademi.

Peterson, R. (2000). A meta-analysis of variance accounted for and factor loadings in

exploratory factor analysis. Marketing Letters, (11), 261-275.

R Core Team. (2013). R: A language and environment for statistical computing, Vienna, Austuria. https://www.R-project.org

Rosseel, Y. (2012). Lavaan: An R package for structural equation modeling and more. Version 0.5-12 (BETA). Journal of Statistical Software, 48(2), 1-36.

Smith, S. (2004). An intervention for school-related behaviours. Elementary School Guidance and Counselling, $28(3), 82-88$.

Schein, E. H. (2011). Leadership and organizational culture. New York, NY: Wiley.

Seligman, M. E.P. (2002). Positive psychology, positive prevention and positive therapy. (Ed: C. R. Synder and S. J. Lopez ). Handbook of positive psychology içinde. The USA: Oxford University.

Şişman, M. (1996). Etkili okul yönetimi. illkokullarda bir araştırma. Yayımlanmamış Araştırma Raporu. Eskişehir: Osmangazi Üniversitesi, Fen Edebiyat Fakültesi.

Tabachnick, B. G. \& Fidell, L. S. (2013). Using multivariate statistics: International edition. Pearson.

Taner, D. (2008). Öğretmenlerin umutsuzluk düzeyi ile okul kültür arasındaki ilişki. Yayımlanmamış yüksek lisans tezi. Yeditepe Üniversitesi, İstanbul, Türkiye.

Tösten, R., \& Özgan, H. (2014). Pozitif psikolojik sermaye ölçeği: geçerlik ve güvenirlik çalışması. Ekev Akademi Dergisi, 18 (59), 429-442.

Uğurlu, C. T. \& Abdurrezzak, S. (2019). A study of validity and reliability of school effectiveness scale, Inonu University Journal of the Faculty of Education, 20 (1), 69-82.

Uğurlu, C. T. \& Demir, A. (2016). Etkili okullar için kim ne yapmalı? Mersin Üniversitesi Eğitim Fakültesi Dergisi, 12 (1) 53-57.

Wang, J.H., Chen, Y.T. \& Hsu, M.H. (2014). A case study on psychological capital and teaching effectiveness in elementary schools. International Journal of Engineering and Technology, 6 (4), 331-337. 
Yalçın, S. (2019). Öğretmenlerin pozitif psikolojik sermaye düzeylerinin incelenmesi. Anadolu Üniversitesi Sosyal Bilimler Dergisi. 19 (1), 13-26.

Yalçın, S., Akan, D. \& Yıldırım, i. (2018) Öğretmenlerin algılarına göre okul yöneticilerinin liderlik stilleri ile öğretmenlerin pozitif psikolojik sermaye düzeyleri arasındaki ilişkinin incelenmesi. Karadeniz Sosyal Bilimler Dergisi, 10 (18), 157-174.

Yıldııım, A. \& Şimşek H. (2016). Sosyal bilimlerde nitel araştırma yöntemleri. Seçkin Yayıncılık.

İletişim/Correspondence

Dr. Davut Atış

davutatis@anadolu.edu.tr

Dr. Öğr. Üyesi Çetin Terzi cterzi@anadolu.edu.tr 